\title{
ТЕХНІЧНЕ ЗАБЕЗПЕЧЕННЯ ПЕРИОПЕРАЦИЙНОЇ КЕРАТОМЕТРІЇ ПРИ ІМПЛАНТАЦІї ІНТРАОКУЛЯРНИХ ЛІНЗ
}

\author{
Полішук О.C., PhD student \\ E_1_@ukr.net \\ Козяр В.В., доц., к.М.н. \\ kozyarvasiliy@gmail.com \\ Національний технічний університет України \\ “Київський політехнічний інститут імені Ігоря Сікорського” \\ м. Київ, Україна
}

Реферат - Дана робота присв'ячена проектуванню та послідуючій технічні реалізацї прилада, изо придатний до використання в сфері офтальмології. Розроблений кератометр на який отримано патент UА 120893 та акт впровадження. Для реалізації прилада було залучено різні допоміжні засоби, такі як: середовища SolidWorks, LabView, 3Ds max та 3D принтер Anet A8. Перед вибором форми кілець для проекиї, було проаналізовано три типи їх розміщення, а саме, площинне, від'ємне конусне та від'ємне параболоїдне розмішення. Програма 3Ds тах застосована для просліддковування ходу променів світла після проходження кониентричних кілець. В приладі міститься плата Arduіпо Місго на базі процесора АТтеgа32и4. Дана плата дає можливість приводити прилад в поступальний рух за допомогою джойстика. Рух по горизонталі передбачений для можливості фокусування камери, шцо міститься в приладі та для більш точного проведення діагностичної прочедури. Кератометр дає змогу провести вимірювання передньої поверхні рогівки ока людини в різних меридіанах. Значення, які отримуються при иьому, оцінються в міліметрах та виводяться в спеціальне вікно програми. Інформачію зручно зберігати на будь якому інформаційному накопичувачу. Маючи дані про нормальну рогівку за допомогою розробленої програми в середовищі LabVIEW та маркерів, щзо проставляються на отриманому зображенні, можливо діагностувати стан передньої поверхні ока, а саме рогівки. Згідно дослідження, шуо було проведене на чотирьох добровольиях, отримано інформаџію, щзо три з них мають певне відхилення від норми, а саме, астигматизм та кератоконус. Даний висновок був зроблений на основі експертного рімення та інформації отриманої від інших авторів в ичій області. Прилад може бути використаним для проведення до та після операційної діагностики, а також, як засіб отримання даних, необхідних для підбору інтраокулярної лінзи. Слідуючими удосконаленнями, які плануються, має бути додання можливості діагностики інших структур ока людини. Такими структурами є задня стінка рогівки ока, райдужна оболонка та кришталик із задньою та передньою стінками капсули.

Ключові слова: IОЛ; інтраокулярна лінза; кератометр; астигматизм; катаракта; LabView; SolidWorks; 3D друк.

\section{І. ВСТУП}

Давня медична мудрість говорить, що добре лікується те, що добре діагностується. Повною мірою це відноситься і до офтальмохірургії, яка забезпечує збереження і відновлення функції основного каналу надходження інформації людині. Досить поширені операції імплантації інтраокулярних лінз (ІОЛ) при катаракті можуть бути неефективними (викликати у пацієнта розчарування), якщо до операції не були виявлені супутні патології ока. Прикладом може бути рогівковий або кришталиковий астигматизм, який зустрічається у $45 \%$ пацієнтів 3 катарактою і при якому потрібна імплантація досить точно орієнтованих торичних лінз [1]. Більше $30 \%$ хірургів впевнені, що помилка орієнтації торичних IОЛ на $10^{\circ} €$ припустимою. Однак результатом такої помилки стане зниження ступеня корекції астигматизму на 33\% [2]. Застосування даного виду лінз в хірургії катаракти $\epsilon$ високоефективним, безпечним способом корекції супутнього астигматизму [3-9]. Необхідно брати до уваги той факт, що розрахунок інтраокулярних лінз потребує введення в формулу ІОЛ вірогідних значень оптичної сили рогівки i $€$ критичним при визначенні необхідних параметрів ІОЛ. За даними деяких авторів, рогівковий астигматизм більше 0,5 діоптрій (дптр.) зустрічається в 46\% випадків, в той час як лише в $4,7 \%$ випадків визначався астигматизм більше 1,5 дптр., причому переважно прямого типу [10, 11]. Пацієнти в яких встановлено астигматизм від 3 до 5 дптр. 3 кератоконусом, більш непередбачувані за результатами операції, що може викликакати додаткові труднощі. Результати дослідження за допомогою приладу Oculus Pentacam показують, що задня поверхня рогівки зазвичай має прямий астигматизм, при якому вертикальний меридіан крутіший в $90 \%$ 
випадків, навіть при прямому або зворотному астигматизмі передньої поверхні. Якщо додати одну одиницю (ступінь) торичності ІОЛ $(\approx 0,75$ дптр.) для зворотнього астигматизму і зменшити на одну ступінь торичність ІОЛ для прямого астигматизму, корекція досягається нута в 90\% випадків. Коли проводять оцінювання задньої поверхні рогівки за допомогою Шаймпфлюгкамери, точність корекції досягає 100\% [2].

Рогівка може мати й інші види відхилень форми передньої поверхні від норми, а саме, кератоконус (дистрофічні процеси рогівки, що викликають іiі деформацію i призводять до зниження зорових функцій), кератоглобус (дегенеративні зміни рогівки, що призводять до витончення ऑii строми; 3 прогресуванням захворювання відбувається випинання рогівки, після чого вона набуває форму кулі), а також патологічні процеси, що виникають в результаті тривалого використання контактних лінз.

Для діагностики цих відхилень використовується кератометрія (офтальмометрія). Проведення такого діагностичного дослідження необхідно і після імплантації ІОЛ, тому що розріз, навіть мінімальний, на краю рогівки може викликати зміни ऑï геометричної форми [12]. Цей тест вимірює величину заломлюючої сили рогівки, яка може бути оцінена радіусом кривизни (мм) або як оптична сила в діоптріях.

Кератометрія є одним 3 провідних методів контрольної діагностики, який застосовується після трансплантації рогівки ока (кератопластика). Результати вимірювання радіуса кривизни рогівки і кришталика мають важливе значення для проведення фоторефракціонной терапія або LASIK (LaserAssisted in Situ Keratomileusis - “лазерний кератомілез”). Діагностику важливо проводити до та після даної терапії, адже внаслідок зменшення товщини рогівки, змінюються ii біомеханічні властивості, а саме: корнеальний гістерезис i фактор резистентності рогової оболонки ока.

Комп'ютерну кератометрію проводять за методиками Жаваля-Шіотца, Шайнера, або Шайнера в модифікації фірми Бауш енд Ломб [13]. В теперішній час на ринку представлені кератометри брендів AXIS, TOMEY, TOPCON, Nidek, але, на жаль, серед них не немає українських моделей. Тому розробка вітчизняного приладу для оцінки форми передньої поверхні рогівки, є актуальною.

Мета роботи: розробка вітчизняного кератометра, дані якого, можуть бути використані при підборі ІОЛ та слугувати показником ефективності проведеного оперативного втручання.

\section{II. МАТЕРІАЛИ ТА МЕТОДИ}

Моделювання складових елементів приладу проводилось в програмному середовищі SolidWorks. Отримані моделі були надруковані нетоксичною пластмасою PLA на 3D принтері Anet A8. За допомогою середовища LabView було розроблене програмне забезпечення для керування приладом та виконання необхідних розрахунків. В складі цього програмного забезпечення виділені (уособлені) два віртуальних прилади: Grablmage To File.vi та Image Measurement.vi. Призначення першого спряження фото-відеокамери із компютером, захват зображення i збереження його у вибраному сховищі. Другий забезпечує вимірювання рогівки в різних меридіанах із точністю 0,01 мм. Поступальний рух забезпечувався за допомогою влаштованої плати Arduino Micro на базі процесора ATmega32u4, та джойстика. Рух по горизонталі передбачений для можливості фокусування камери, що міститься в приладі та для більш точного проведення діагностичної процедури.

Працездатність, функціонування приладу за призначенням підтверджене в натурному експерименті (на добровольцях).

\section{ІІІ. РОЗРОБКА ПРИЛАДУ}

В розробленому приладі використано метод Placido, який передбачає аналіз форми кільцевих фігур, спроектованих на передню поверхню рогівки [14], (рис.1, 2). Після аналізу варіантів розміщення тестових зображень для проекції на око людини, обрано 12 кілець Placido, розташованих на конічній поверхні [15], що забезпечує рівномірність проміжків між проекціями і дозволяє оцінити кривизну рогівки, як в центральній частині, так і на їі периферії (рис.3). Матеріал, з якого виготовлені кільця є світловим фільтром для безпеки ока людини. За допомогою проекції кільцевих тіней на око стає можливим виявити відхилення форми передньої поверхні рогвки від сферичної. 


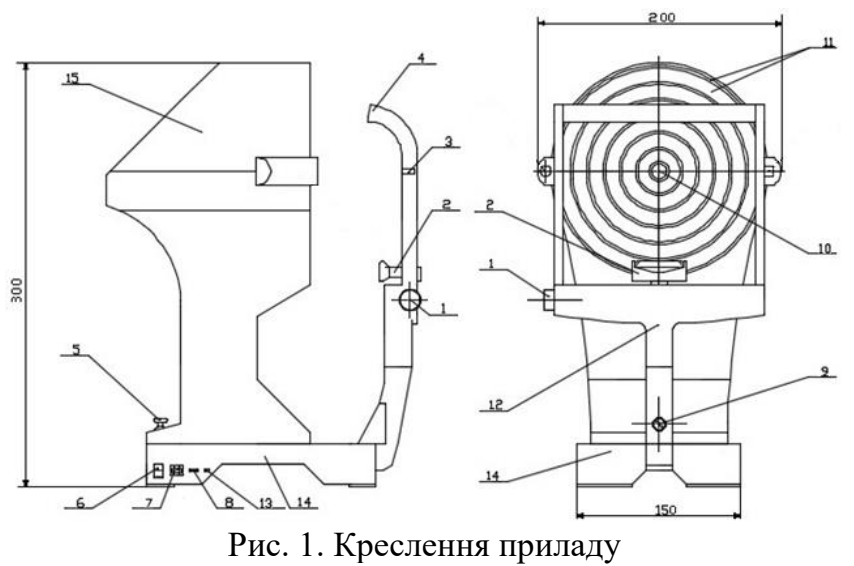

1-Ручка-коліщатко, 2-підставка для підборіддя, 3мітка висоти очей, 4-упор для лобу, 5-джойстик керування, 6-кнопка вкл/викл, 7-USB-порт, 8-роз'єм живлення, 9-гвинт, 10-фотокамера, 11-кільця, 12фіксатор голови, 13-індикатор включення, 14платформа, 15-затвор.

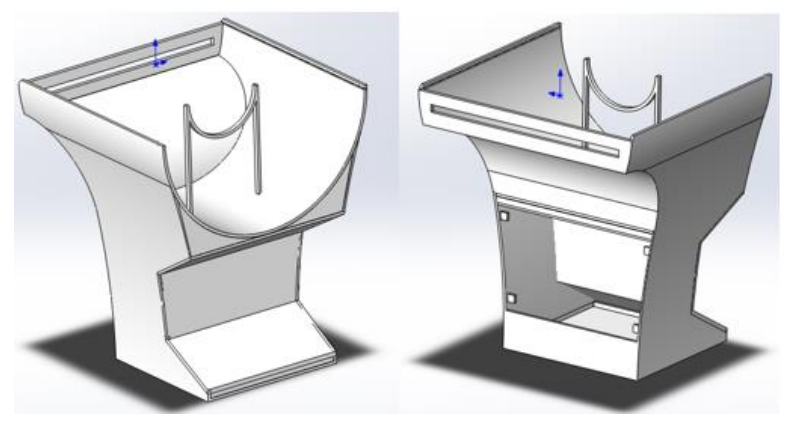

Рис. 2. 3D модель корпуса кератометра, розробленого в SolidWorks

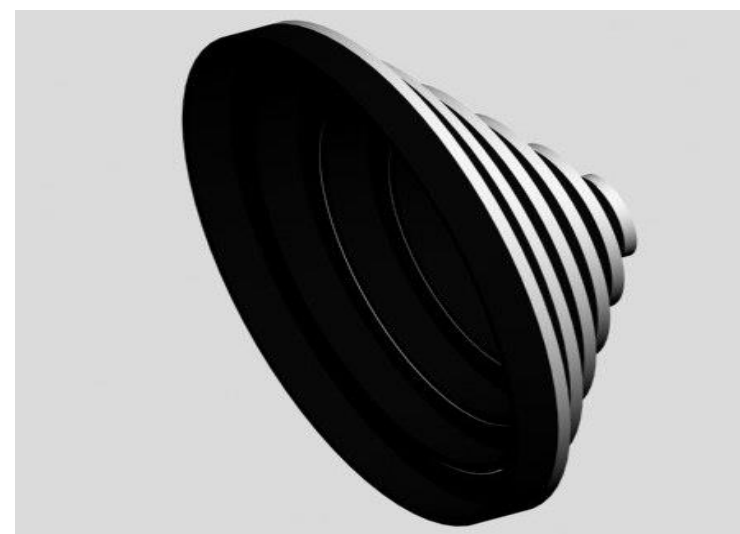

Рис. 3. Конусне розташування кілець Placido для проекції

Для проекції кілець на око використане світлодіодне джерело освітлення, світловий потік якого становить 870 лм, а інтенсивність $14.4 \mathrm{BT} / \mathrm{M}^{2}$. Було проведено дослідження проекції на око кілець Placido при площинному, від'ємному конусному, від'ємному параболоїдному їх розміщеннях. Моделювання цих кілець та їх аналіз проводився в середовищах Solidworks i 3Ds $\max [16]$. Було виділено саме три типи цих розміщень, що дає можливість провести порівняння отриманих проекцій та визначити переваги та недоліки кожного з них. Наочне предствлення отриманих моделе, зобрежено на рис. 4.
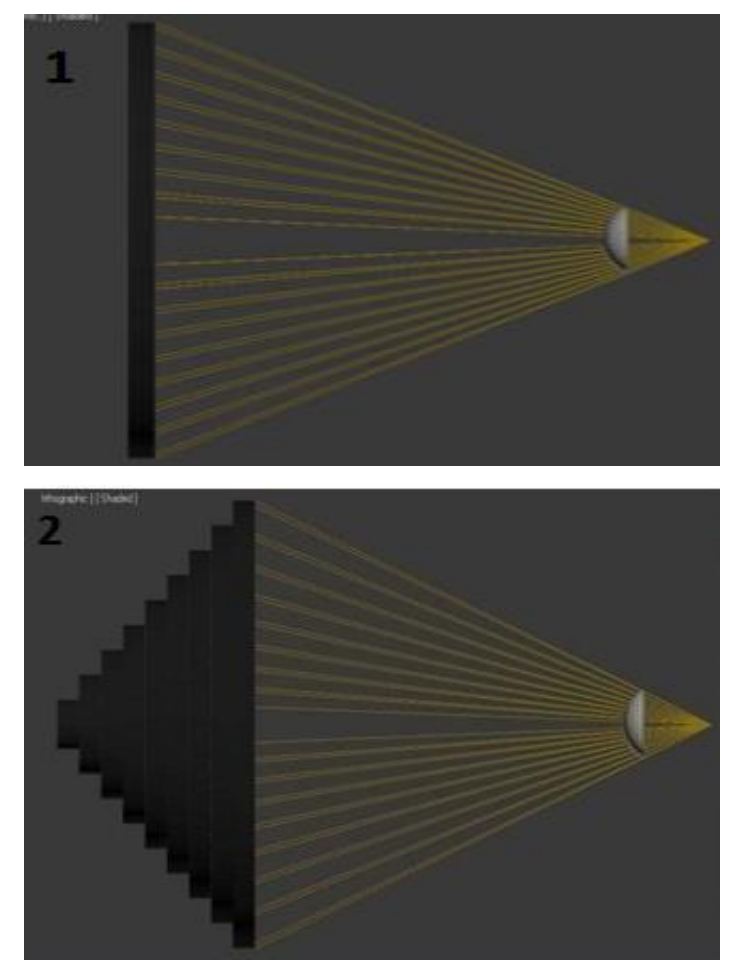

3

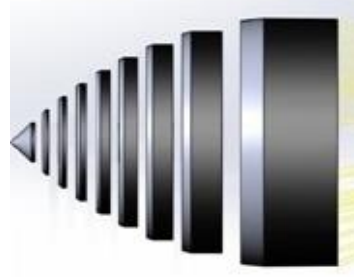

Рис. 4.Результат моделювання

На рис.4. в лівій частини представлені змодельовіані кільця для проекції на око людини, в правій частині цього ж рисунка змодельована рогівка. Програмні середовища в яких відбувалось моделювання, даючть змогу проваести аналіз ходу променів (проекціі) 3 кілець на рогівку.

Провівши відповідний аналіз, було обрано конусну форму розташування концентричних кілець. Таке геометричне розміщення не спричиняло споворення форми на оці під час проекції. Джерело освітлення розміщене в приладі за кільцями. Таким чином при ввімкнені прилада було отримано зображення цих кілець 
на рогівці. В центральній частині кілець знаходиться фото-відео камера, що дає змогу реєструвати зображення для наступного його аналізу в попередньо розробленій програмі. Після перевірки всіх функціональних частин зібрано прилад, який показаний на рис.5.

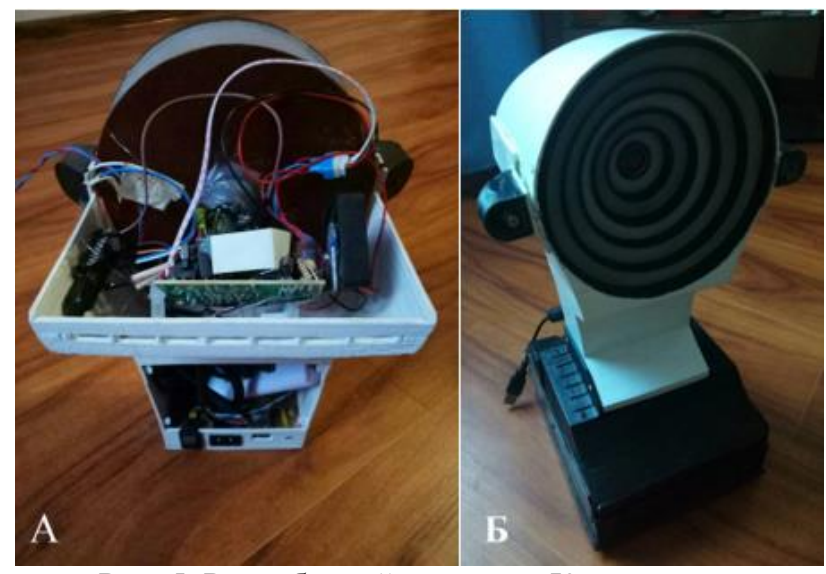

Рис. 5. Розроблений прототип Кератометра

A - прилад без кришки та затвору

Б - зібраний прилад, вид спереду

За допомогою створеного в програмному середовищі LabVIEW віртуального приладу (ВП) Grablmage To File.vi (рис.6.), який попередньо встановлений на комп'ютер, фотовідео камера підключалась до СОМ порту цього ж комп'ютера, здійснювався захват зображення, яке надалі зберігалося у вказаній папці.

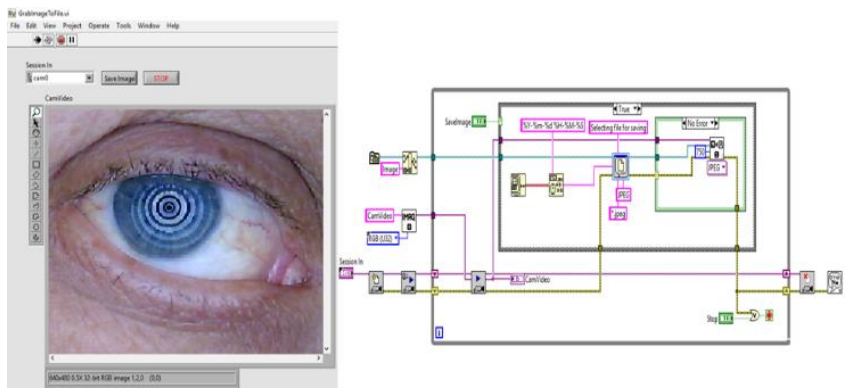

Рис. 6. Код програми GrablmageToFile

Дослідження за допомогою створеного кератометра виконувались наступним чином. Прилад підключався до мережі 220В/50Гц, його USB-порт за допомогою проводу з'єднувався із комп'ютером, на якому було встановлене програмне забезпечення для роботи кератометра, після чого вмикалася кнопка включення. Світіння індикатора в основі приладу свідчило про його робочий стан i працездатність. Пацієнт розташовувався перед пристроєм, розміщуючи підборіддя на підставці таким чином, щоб чолом доторкатися до упора для лоба, а очі знаходились на одній лінії 3 міткою висоти очей. Якщо цього не відбувалося, потрібно було регулювати положення фіксатора голови ручкою-коліщатком. Після цього медичний працівник фокусвав прилад джойстиком для отримання чіткого зображення i виконував зйомку джойстиком або за допомогою встановленої на комп'ютері чи іншому девайсі програми. Далі програма виконувала заміри рогівки за допомогою попередньо проставлених медичним працівником маркерів і на монітор комп'ютера виводила результати в міліметрах. Обрана кількість кільцевих проекцій надала можливість оцінити сферичність усієї поверхні рогівки. Наявність в приладі рухомої платформи-основи і джойстика керування підвищувала якість та точність фокусування оптичної системи при індивідуальному налаштуванні положення голови пацієнта.

\section{IV. КЛІНІЧНА АПРОБАЦІЯ I ОБГОВОРЕННЯ}

Застосування спеціально розробленого в складі мультифункціонального загального програмного забезпечення віртуального приладу Image Measurement.vi та додаткової бібліотека програм NI Vision Acquisition Software дало змогу провести вимірювання кривизни рогівки ока людини в різних меридіанах (рис.7). Обов'язковою умовою було розміщення очей досліджуваного на відстані $10 \mathrm{~cm}$ від переднього краю конічної поверхні з кільцями. При цьому досягалася оптимальна якість спроектованого на рогівку зображення. При потребі за допомогою рухомого підборідника та горизонтального переміщення приладу положення голови досліджуваного корегувалося.

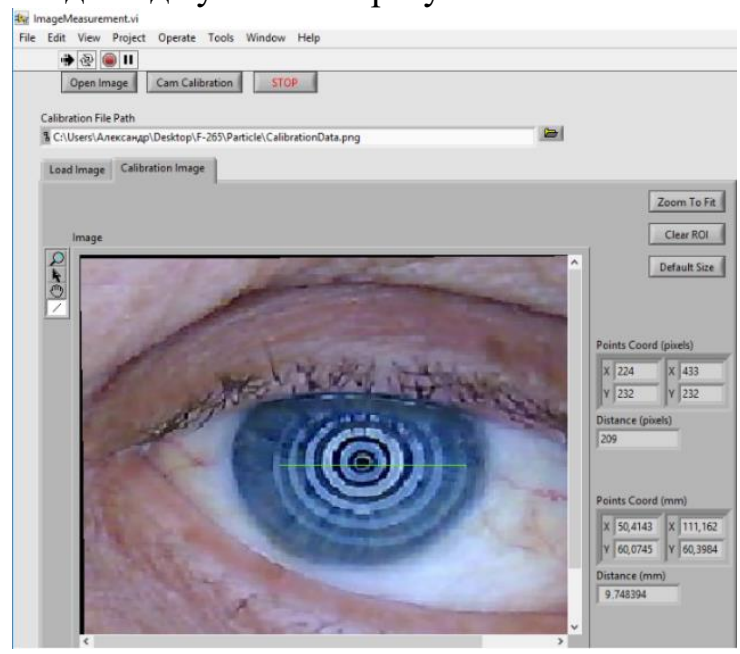

Рис. 7. Вимірювання кривизни рогівки за допомогою розробленої програми Image Measurement 
Згідно числових даних, отриманих в результаті вимірювання, а саме: горизонтальний розмір рогівки 9,74 мм і вертикальний - 9,21 мм. Так як діаметр рогівки варіюється в дуже незначних межах $\mathrm{i}$ становить $10 \pm 0,56$ мм, беручи до уваги, що вертикальний розмір зазвичай на 0,5-1 мм менше горизонтального, є підстави вважати, що у пацієнта наявні астигматизм та кератоконус. Такий діагноз підтверджується за допомогою модуля NI Vision Development і функцій: IMAQ Convert Pixel to Real World VI та IMAQ Point Distances VI, які дають можливість виміряти проекцію кілець Placido, та отримати числове значення викривлення рогівки в міліметрах. Подібні дослідження і оцінка проекцій кілець Placido були проведені при дослідженні 4-х добровольців і результати показані на рис.8.
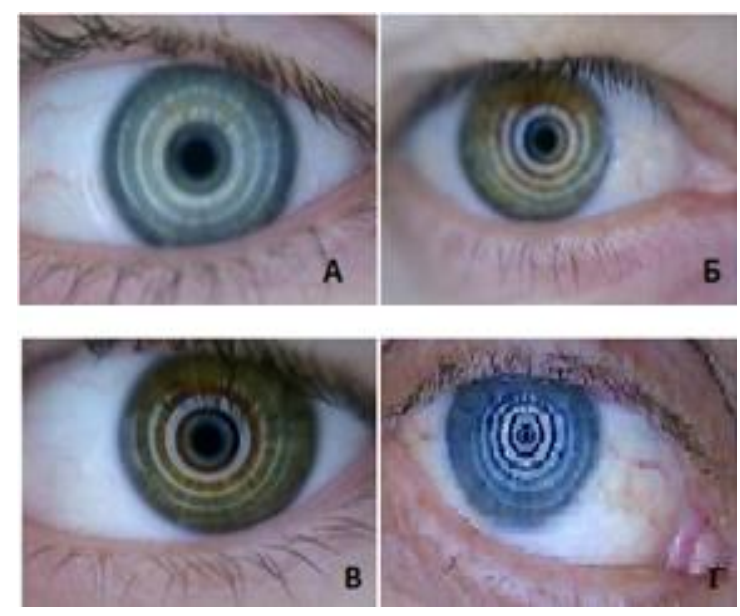

Рис. 8. Зображення, отримані за допомогою розробленого кератометра

Діагностична інформація, яку отримують про кератометрії за допомогою кілець Placido (рис. 9), в стиснутому вигляді є такою:

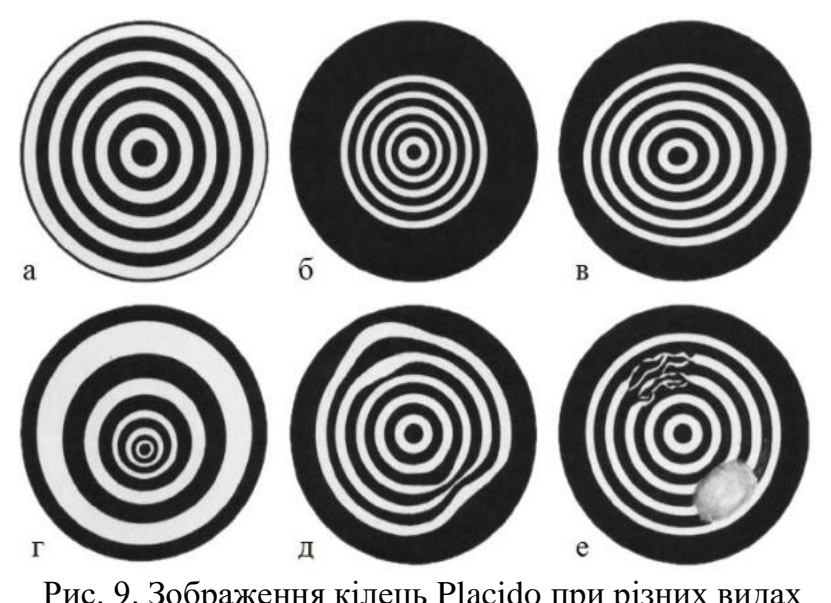

Рис. 9. Зображення кілець Placido при різних видах патологій [17]
А, Б). Рогівка, у якій радіус більший, ніж нормальний, характеризується на кератограмі більшим радіусом кілець. Навпаки, якщо радіус рогівки менше норми, то кільця зменшені.

B). Астигматизм характеризується на кератограмах еліптичною формою зображення кілець.

Г). При кератоконусі кільця зменшені в області його вершини, де радіус поверхні малий, і розширені в периферичній сплюснутій частині.

Д). Місцеві сплощення рогівки викликають на відповідних ділянках зображення розширення кілець, а більш опуклі ділянки характеризуються звуженням кілець.

Е). Якщо рогівка має хвилясту, зморщену поверхню, що буває при кератитах, зображення кілець зникає і з'являється переплетення ліній неправильної форми. Ті ділянки рогівки, де порушена нормальна структура епітелію, на кератограмах характеризуються зникненням чіткого малюнка.

Порівняння отриманих зображень із даними інших авторів [17] надало змогу зробити такі заключення: Встановлено, що рис. 8 (А) не містить інформації про викривлення рогівки. На рис. 8 (Б) 4-й диск зміщений в сторону слизового м'язця, наступні, 5-й та 6-й диски, значно витянуті i ïx практично не можливо ідентифікуватиі, всі вони не зберігають свою товщину. На рис. 8 (В) диски різної товщини, а на рис. 8 (Г) 8-ме та 9-те кільця витянуті в бік слизового м'язця, не зберігають сталість проміжків між собою, що $є$ ознаками астигматизму та кератоконусу.

Розроблений прилад, за допомогою вище зазначених елементів, дає змогу проводити заміри рогівки в різних меридіанах, що дозволяє здійснити точний розрахунок перед імплантацією торичних лінз та підвищити цим самим якість корекції ступеня астигматизму.

\section{ВИСНОВКИ}

1. В результаті проведеної роботи, було успішно досягнено поставлену в дослідженні мету. Доведена принципова можливість виготовлення вітчизняного кератометра, який потребує подальшої метрологічної експертизи i верифікації точності отриманих характеристик.

2. Розроблений кератометр, в принципі, дозволяє вимірювати кривизну рогівки в різних меридіанах,

3. Отримана інформація в діоптріях та мм, може бути використана для підбору 
інтраокулярних лінз, а також для, як до-, так i післяопераційної діагностики.

\section{ПЕРЕЛІК ПОСИЛАНЬ}

[1] Перегудов Д.В., Муравьева Е.В., Сарапулова Е.В. Сравнительный анализ клинических результатов факоэмульсификации катаракты $\mathrm{c}$ имплантацией ИОЛ ACRYSOF IQ TORIC SN6AT2-T9 (ALCON), рассчитанных на рекомендованном (кератотопограф и оптический биометр) и доступном (авторефкератометр и А-скан) оборудовании у лиц с регулярным астигматизмом/ Д.В. Перегудов, Е.В. Муравьева, Е.В.Сарапулова// Хирургия катаракты, оптикореконструктивная хирургия. Екатеринбург. 2015. С. 36-42.

[2] The New Era in Astigmatism management: Techniques and Technologies that shatter old concepts // Ocular Surgery News. 2014. - Suppl. - 19 p.

[3] Малюгин Б.Э.Хирургия катаракты и интраокулярная коррекция на современном этапе развития офтальмохирургии // Вестник офтальмологии. - 2014. - Т. 130, № 6. - С. 80-88.

[4] Трубилин В.Н., Ильинская И.А. Метод интраокулярной коррекции астигматизма. Методические рекомендации ФМБА. M., 2012. -35 c.

[5] Федяшев Г.А.Коррекция астигматизма торическими интраокулярными линзами у пациентов, оперирующихся по поводу катаракты. Обзор литературы // Офтальмология. - 2013 T. 10, № 2. - C. 8-12.

[6] Шантурова М.А., Сенченко Н.Я. Имплантация торических ИОЛ - эффективный, предсказуемый способ коррекции роговичного астигматизма // Бюллетень Восточно-Сибирского научного центра СО РАМН. - 2011. - № 6. - С. 113-115.
[7] Юсеф Ю.Н., Юсеф С.Н., Иванов М.Н. и др. Современные методы коррекции астигматизма в хирургии катаракты // Вестник офтальмологии. - 2014. - Т. 130, № 1. - С.91-95.

[8] Alio J.L., Agdeppa M.C., Pongo V.C. et al. Microincision cataract surgery with toric intraocular lens implantation for correcting moderate and high astigmatism: pilot study // J. Cataract Refract. Surg. - 2010. - Vol. 36, № 1. - P. 44-52.

[9] Chang D.F. Mastering refractive IOLs; the art and science. Thorofare: SLACK incorporated, 2008. - 895 p.

[10] Satterfield D.S. Prevalence and variation of astigmatism in a military population. J. Am. Optom Assoc. 1989; 60: 14-18.

[11] Fledelius H.C., Stubgaard M. Changes in refraction and corneal curvature during growth and adult life. A cross sectional study. Acta Ophthalmol. (Copenh). 1986; 64: 487-491.

[12] Поліщук О.С., Козяр В.В. Конструктивні рішення для попередження розвитку вторинної катаракти після імплантації інтраокулярних лінз/ О.С. Поліщук, В.В. Козяр// Innov Biosyst Bioeng, 2020, vol. 4, no. 1, C. 36-44. DOI: https://doi.org/10.20535/ibb.2020.4.1.187310

[13] Гутмарк Р, Гайтон Д.Л. Происхождение кератометра и его развивающаяся роль в офтальмологии. Обзор офтальмологии 2010; 55 (5): 481-497.

[14] Алямовский A.A. SolidWorksSimulation как решать практические задачи / А.А. Алямовский. - М.: БХВ Петербург, $2012.443 \mathrm{c}$.

[15] Пат. 120893 Україна, МПК (2017.01) А61В 3/107 (2006.01) G02B 6/00. Автофотокеатометр/Поліщук О.С.; заявл. 18.05.2017 ; опубл. 27.11.2017, Бюл. № 223.

[16]Горелик А.М. Самоучитель 3dsMax 2014 / А.М. Горелик. М.: БХВ Петербург, 2014.

[17] Пучковская Н.А. Атлас глазных болезней / Н.А. Пучковская: АМН СССР. - М.: Медицина, 1981. 368 с. 


\section{ТЕХНИЧЕСКОЕ ОБЕСПЕЧЕНИЕ ПЕРИОПЕРАЦИОННОЙ КЕРАТОМЕТРИИ ПРИ ИМПЛАНТАЦИИ ИНТРАОКУЛЯРНЫХ ЛИНЗ}

Полишук А.C., PhD student. E_1_@ukr.net

Козяр В.В., доц.,К.М.Н kozyarvasiliy@gmail.com Национальный технический университет Украины "Киевский политехнический институт имени Игоря Сикорского" г. Киев, Украина

Реферат - Данная работа посвящена проектированию и последующей технические реализации прибора, что пригодный к использованию в сфере офтальмологии. Разработанный кератометр, на который получен патент UA 120893 и акт внедрения. Для реализации прибора были привлечены различные вспомогательные средства, такие как: среды SolidWorks, LabView, 3Ds max и 3D принтер Апеt A8. Перед выбором формы колеи для проекции, были проанализированы три типа их размещения, а именно, плоскостное, отрицательное конусное и отрицательное параболоидное размещения. Программа 3Ds тах применена для анализа хода лучей света, после проходжения концентричесних колец. В приборе содержится плата Аrdиіпо Місго на базе процессора ATтеgа32u4. Данная плата позволяет приводить прибор в поступательное движение с помощью джойстика. Движение по горизонтали предусмотрено для возможности фокусировки камеры, что содержится в приборе и для более точного проведения диагностической прочедуры. Кератометр позволяет провести измерения передней поверхности роговицы глаза человека в разных меридианах. Значения, получаемые при этом, оциванються в миллиметрах и выводятся в специальное окно программы. Информацию удобно хранить на любом информационном накопителю. Имея данные о нормальной роговииу с помощью разработанной программы в среде LabVIEW и маркеров, что проставляются на полученном изображении, возможно диагностировать состояние передней поверхности глаза, а именно роговищы. Согласно исследованию, которое было проведено на четырех добровольцах, получена информация, что три из них имеют определенное отклонение от нормы, а именно, астигматизм и кератоконус. Данный вывод был сделан на основе экспертного решения и информации, полученной от других авторов в этой области. Прибор может быть использован для проведения до и после операчионной диагностики, а также как средство получения данньх, необходимых для подбора интраокулярной линзы. Следующими усовершенствованиями, которые планируются, долэно быть придания возможности диагностики других структур глаза человека. Такими структурами есть задняя стенка роговищы глаза, радужная оболочка и хрусталик с задней и передней стенками капсульы.

Ключевые слова: ИОЛ; интраокулярная линза; кератометр; астигматизм; катаракта; LabView; SolidWorks; 3D nечать. 


\title{
TECHNICAL SUPPORT OF PERIOPERATIVE KERATOMETRY DURING INTRAOCULAR LENSES IMPLANTATION
}

\author{
Polischuk O.S., PhD student. \\ E11@ukr.net \\ Kozyar V.V., PhD. in Medicine \\ kozyarvasiliy@gmail.com \\ National Technical University of Ukraine \\ "Igor Sikorsky Kyiv Polytechnic Institute" \\ Kiev, Ukraine
}

\begin{abstract}
This article is devoted to the design and subsequent technical implementation of the device, which is suitable for use in the field of ophthalmology. The developed keratometer for which the patent UA 120893 and the act of implementation were received. To implement the device, various auxiliary tools were involved, such as: SolidWorks environments, LabView, 3Ds max and Anet A8 3D printer. Before choosing the shape of the rings for the projection, three types of their placement were analyzed, namely, planar, negative cone and ne gative paraboloid placement. The 3Ds max program is used to analyze the path of light rays after passing through the concentric rings. The device contains an Arduino Micro board based on an ATmega32u4 processor. This board allows you to move the device in translational motion using a joystick. The horizontal movement is provided for the possibility of focusing the camera, which is contained in the device and for a more accurate diagnostic procedure. The keratometer allows you to measure the anterior surface of the human cornea in different meridians. The values obtained in this case are measured in millimeters and displayed in a special window of the program. It is convenient to store information on any information storage device. Having data on the normal cornea using the developed program in the LabVIEW environment and markers that are affixed to the resulting image, it is possible to diagnose the condition of the anterior surface of the eye, namely the cornea. According to a study that was conducted on four volunteers, information was obtained that three of them have a certain deviation from the norm, namely, astigmatism and keratoconus. This conclusion was made on the basis of expert judgment and information received from other authors in this area. The device can be used for carrying out before and after surgical diagnostics, as well as a means of obtaining the data necessary for the selection of an intraocular lens. The next improvements that are planned should be to make it possible to diagnose other structures of the human eye. These structures are the posterior wall of the cornea of the eye, the iris and the lens with the posterior and anterior walls of the capsule.
\end{abstract}

Keywords: IOL; intraocular lens; keratometer; astigmatism; cataract; LabView; SolidWorks; 3D printing. 